\title{
Correction to: Stereotactic Ablative Radiotherapy (SABR/SBRT) for Hepatocellular Carcinoma
}

\author{
Byung-Han Rhieu ${ }^{1} \cdot$ Amol K. Narang ${ }^{1} \cdot$ Jeffrey Meyer ${ }^{1}$
}

Published online: 16 September 2019

(C) The Author(s) 2019

\section{Correction to: Current Hepatology Reports (2018) 17(4):392-398 https://doi.org/10.1007/s11901-018-0436-4}

The article Stereotactic Ablative Radiotherapy (SABR/SBRT) for Hepatocellular Carcinoma, written by Byung-Han Rhieu, Amol K. Narang and Jeffrey Meyer, was originally published electronically on the publisher's internet portal (currently SpringerLink) on 16 October 2018 without open access.

With the author(s)' decision to opt for Open Choice the copyright of the article changed on September 2019 to (C) The Author(s) 2019 and the article is forthwith distributed under the terms of the Creative Commons Attribution 4.0 International License (http://creativecommons.org/licenses/ by/4.0/), which permits use, duplication, adaptation, distribution and reproduction in any medium or format, as long as you give appropriate credit to the original author(s) and the source, provide a link to the Creative Commons license and indicate if changes were made.

Open Access This article is distributed under the terms of the Creative Commons Attribution 4.0 International License (http:// creativecommons.org/licenses/by/4.0/), which permits unrestricted use, distribution, and reproduction in any medium, provided you give appropriate credit to the original author(s) and the source, provide a link to the Creative Commons license, and indicate if changes were made.

Publisher's Note Springer Nature remains neutral with regard to jurisdictional claims in publishedmaps and institutional affiliations.

The online version of the original article can be found at https://doi.org/ 10.1007/s11901-018-0436-4

Byung-Han Rhieu

brhieu1@jhmi.edu

1 Department of Radiation Oncology, Johns Hopkins Hospital, 401 North Broadway / Suite 1440, Baltimore, MD 15213, USA 